\title{
Annual distribution and activity of phytoplankton in the Skagerrak/Kattegat frontal region
}

\author{
J. P. Heilmann ${ }^{1}$, K. Richardson ${ }^{1}$, G. Ertebjerg ${ }^{2}$ \\ ${ }^{1}$ Danish Institute for Fisheries and Marine Research, Charlottenlund Castle, DK-2920 Charlottenlund, Denmark \\ ${ }^{2}$ National Environmental Research Institute, Frederiksborgvej 399, Postboks 358, DK-4000 Roskilde, Denmark
}

\begin{abstract}
Data from 15 cruises conducted in the northern Kattegat and southern Skagerrak at different times of the year during the period 1984 to 1993 were collated and analysed in an attempt to identify the effect that the Skagerrak/Kattegat frontal system may have on the annual distribution of phytoplankton biomass and activity in this region. The location of the front is transient and, on some cruises, it was not observed. However, when present, it occurred most often within the latitudinal boundaries of $57^{\circ} 25^{\prime} \mathrm{N}$ and $58^{\circ} 00^{\prime} \mathrm{N}$ (here referred to as the 'frontal region'). Phytoplankton biomass (expressed as depth-integrated chlorophyll to $30 \mathrm{~m}$ ) was shown to be significantly higher in the frontal region than in surrounding waters. During periods when light limitation of primary production was predicted, the biomass maximum associated with the front was found in the weakly stratified waters bordering the front. During summer, the biomass maximum associated with the front was generally recorded at the most weakly stratified stations (where nutrient-rich bottom water extends highest into the photic zone). Total annual primary production for the entire study area was estimated to be approximately $190 \mathrm{~g} \mathrm{C} \mathrm{m}^{-2} \mathrm{yr}^{-1}$. The data set was not sufficient to identify significant differences in primary production in and outside the frontal region. During the period from about April to October, the phytoplankton distribution was characterised by the presence of a subsurface chlorophyll maximum. This maximum was usually associated with the upper layer of the nutrient-rich bottom waters (i.e. the bottom of the pycnocline) and phytoplankton in the surface waters showed signs of nutrient depletion during the same period. Seven of the cruises included in the study were carried out during May but in different years. Significant differences in the distribution of phytoplankton in the water column were shown between these years but no significant difference in primary production could be demonstrated.
\end{abstract}

KEY WORDS: Primary production · Chlorophyll $a \cdot$ Phytoplankton biomass $\cdot$ Front

\section{INTRODUCTION}

Together, the Skagerrak and Kattegat form the transition zone between the North Sea and the Baltic. Geographically, the border between the Skagerrak and the Kattegat is defined as being a line from Skagen (the most northerly point in Jutland) to the Swedish coast at $57^{\circ} 44.8^{\prime} \mathrm{N}$ (Helsinki Convention). However, the hydrographic border ('Skagerrak/ Kattegat front') separating the 2 water types that characterise these seas is quite variable in position.

In general, it can be said that the Skagerrak is primarily influenced by the North Sea while the Kattegat is characterised by surface waters that have their origin in outflowing Baltic water and bottom water originating in the North Sea/Skagerrak. The Skager$\mathrm{rak} /$ Kattegat front has been defined in earlier literature as being at the location of the density change between Kattegat and Skagerrak surface waters, and its position is a consequence of volume fluxes in the Skagerrak (Poulsen 1991). During the period from about April to September/October, the outflow from the Baltic is generally large and the wind field small relative to the annual averages. During this period, the front is quite stable and is positioned in the northern Kattegat. From October/November until about March, Baltic outflow is small and wind speeds large relative to annual averages. At this time, the front is unstable (Poulsen 1991, Rodhe 1992, Jakobsen et al. 1994). 
Although the Skagerrak/Kattegat front is a predictable feature during the biologically most active period of the year, the potential influence that this frontal system may have on biological processes occurring in this region has not been well studied. Richardson (1985) examined phytoplankton distribution and activity in the northern Kattegat/southern Skagerrak in April 1984 and found evidence of increased phytoplankton activity in the northern Kattegat as well as at the boundary (front) between the Skagerrak and the North Sea. However, at the time of this study the Skagerrak/Kattegat front was not well established and the elevated production observed may have been associated with an eddy of Skagerrak water located in the northern Kattegat. In addition, this study was carried out over a very short time period and can hardly be used as a basis for describing the potential effect that the frontal system at the Kattegat/Skagerrak border may have on energy fixation and transfer within the ecosystem over an annual cycle.

The purpose of the present study was to examine as many data sets as possible from different cruises in the boundary region between the Skagerrak and Kattegat from which comparable hydrography and primary production measurements were collected in order to assess the potential impact of this frontal region on production processes occurring there. The null hypothesis for the study was that, although chlorophyll concentrations and primary production estimates exhibit a patchy distribution on individual cruises, there is no difference in the distribution of phytoplankton biomass and activity in the geographical region studied over an annual cycle.

Because of the difficulties in comparing primary production estimates originating from different laboratories (Richardson 1991), only data collected by the same group at the Danish Institute for Fisheries and Marine Research were included in the analysis. In all, data from 15 individual cruises were used in the study. This data set included data collected during May over 7 different years, allowing a comparison of interannual variability in results.

\section{MATERIALS AND METHODS}

Data collection. The study area is shown in Fig. 1. Of the 15 cruises (Table 1) from which data were used, 13 were carried out on the RV 'Dana' (Danish Fisheries Ministry). The remaining 2 (March 2 to 12 and September 21 to 30,1992 ) took place with the RV 'Gunnar Thorson' (Danish Environmental Ministry). The data used in the analysis had been collected for a variety of purposes and the cruises from which they originated did not share a common station net. Therefore, a tran-

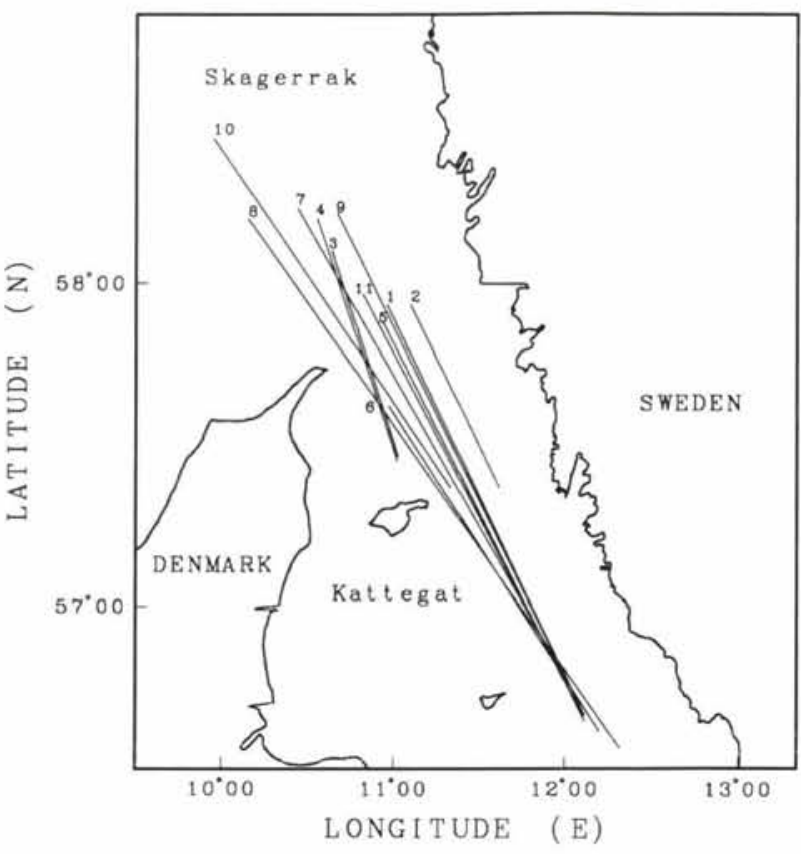

Fig. 1. Study area showing all transects included in the study. The dates for the transects are as follows: 1, Mar 2-3, 1992; 2. Mar 11, 1992; 3, Apr 4, 1984; 4, Apr 14, 1984; 5, May 1-4, 1991; 6, May 13-15, 1993; 7. Jul 19-21, 1992; 8, Aug 17-26. 1988; 9, Sep 21-22, 1992; 10, Oct 17, 1990; 11, Nov $2-4,1990$

sect running through the southern part of the Skagerrak and the northern Kattegat was arbitrarily defined. Care was taken that this transect did not encroach upon the coastal waters where other features (e.g. Norwegian Coastal Current) influence hydrography and production. With the exception of a few stations in the northernmost part of the study area (Skagerrak), stations whose positions were within ca $15 \mathrm{~km}$ of the transect were selected for the analysis. Again, only stations that did not exhibit a strong influence of coastal processes were included. Although the stations selected from each cruise did not necessarily lie in a straight line, they were treated in the subsequent analysis as a 'transect' along a latitudinal gradient. The location of all of these transects can been seen in Fig. 1.

As a minimum criterion for inclusion of a data set, there had to be hydrographic (CTD) and fluorescence (chlorophyll a) data. On all but 2 cruises, discrete samples of chlorophyll a taken for calibration of the fluorescence profiles were also made. On 11 of the cruises, primary production determinations were carried out on some stations. Table 1 shows the dates for the cruises and the types of data available.

Hydrographic data. On the RV 'Dana', temperature and salinity data were collected using a Neil Brown (Mark III) CTD fitted with a rosette of water bottles (Hydrobios) (Nielsen et al. 1993). The RV 'Gunnar 
Table 1. Dates of sampling and positions of transects considered in this study. For data sets where it was not possible to construct transects, cruise dates only are given. Types of data available from each cruise are also indicated

\begin{tabular}{|c|c|c|c|c|c|}
\hline Period & $\begin{array}{l}\text { End points of } \\
\text { selected transect }\end{array}$ & $\begin{array}{c}\text { No. of } \\
\text { stations }\end{array}$ & Chlorophyll & $\begin{array}{l}\text { Absorption } \\
\mathrm{A}_{480} / \mathrm{A}_{665}\end{array}$ & $\begin{array}{l}\text { Primary } \\
\text { production }\end{array}$ \\
\hline Mar 2-3, 1992 & $\begin{array}{l}56^{\circ} 40^{\prime} \mathrm{N}, 12^{\circ} 07^{\prime} \mathrm{E} \\
57^{\circ} 56^{\prime} \mathrm{N}, 10^{\circ} 57^{\prime} \mathrm{E}\end{array}$ & 18 & $\mathrm{x}$ & $\mathrm{x}$ & $x$ \\
\hline Mar 11, 1992 & $\begin{array}{l}57^{\circ} 22^{\prime} \mathrm{N}, 11^{\circ} 37^{\prime} \mathrm{E} \\
57^{\circ} 55^{\prime} \mathrm{N}, 11^{\circ} 06^{\prime} \mathrm{E}\end{array}$ & 14 & $\mathrm{x}$ & $\mathrm{x}$ & $x$ \\
\hline Apr 4,1984 & $\begin{array}{l}58^{\circ} 06^{\prime} \mathrm{N}, 10^{\circ} 37^{\prime} \mathrm{E} \\
57^{\circ} 28^{\prime} \mathrm{N}, 11^{\circ} 01^{\prime} \mathrm{E}\end{array}$ & 7 & $\mathrm{x}$ & & \\
\hline Apr 14,1984 & $\begin{array}{l}58^{\circ} 12^{\prime} \mathrm{N}, 10^{\circ} 33^{\prime} \mathrm{E} \\
57^{\circ} 27^{\prime} \mathrm{N}, 11^{\circ} 01^{\prime} \mathrm{E}\end{array}$ & 8 & $\mathrm{x}$ & & $X^{a}$ \\
\hline May $22-24,1987$ & Not on transect & 5 & $\mathrm{x}$ & $\mathrm{x}$ & $\mathrm{x}$ \\
\hline May $17-21,1988$ & Not on transect & 9 & $\mathrm{x}$ & $\mathrm{x}$ & $\mathrm{X}$ \\
\hline May $1-5,1989$ & Not on transect & 14 & $\mathrm{x}$ & $\mathrm{x}$ & \\
\hline Apr 28-May 3, 1990 & Not on transect & 12 & $\mathrm{x}$ & $\mathrm{x}$ & $\mathrm{x}$ \\
\hline May $1-5,1991$ & $\begin{array}{l}56^{\circ} 37^{\prime} \mathrm{N}, 12^{\circ} 12^{\prime} \mathrm{E} \\
57^{\circ} 43^{\prime} \mathrm{N}, 10^{\circ} 52^{\prime} \mathrm{E}\end{array}$ & 8 & $\mathrm{X}$ & $\mathrm{X}$ & $\mathrm{X}$ \\
\hline May $1-4,1992$ & Not on transect & 12 & $\mathrm{X}$ & $\mathrm{X}$ & $\mathrm{X}$ \\
\hline May $13-15,1993$ & $\begin{array}{l}57^{\circ} 53^{\prime} \mathrm{N}, 10^{\circ} 56^{\prime} \mathrm{E} \\
56^{\circ} 39^{\prime} \mathrm{N}, 12^{\circ} 07^{\prime} \mathrm{E}\end{array}$ & 9 & $\mathrm{X}$ & $\mathrm{X}$ & $\mathrm{X}$ \\
\hline Jun $1-2,1987$ & Not on transect & 10 & & & \\
\hline Jul 19-21, 1992 & $\begin{array}{l}56^{\circ} 42^{\prime} \mathrm{N}, 12^{\circ} 15^{\prime} \mathrm{E} \\
58^{\circ} 16^{\prime} \mathrm{N}, 10^{\circ} 16^{\prime} \mathrm{E}\end{array}$ & 6 & & & \\
\hline Aug 26, 1988 & $\begin{array}{l}58^{\circ} 12^{\prime} \mathrm{N}, 10^{\circ} 09^{\prime} \mathrm{E} \\
56^{\circ} 34^{\prime} \mathrm{N}, 12^{\circ} 19^{\prime} \mathrm{E}\end{array}$ & 8 & $\mathrm{X}$ & $\mathrm{X}$ & \\
\hline Sep 21-22, 1992 & $\begin{array}{l}58^{\circ} 13^{\prime} \mathrm{N}, 10^{\circ} 40^{\prime} \mathrm{E} \\
56^{\circ} 40^{\prime} \mathrm{N}, 12^{\circ} 07^{\prime} \mathrm{E}\end{array}$ & 22 & $\mathrm{x}$ & $\mathrm{X}$ & $x^{b}$ \\
\hline Oct 17,1990 & $\begin{array}{l}58^{\circ} 27^{\prime} \mathrm{N}, 09^{\circ} 57^{\prime} \mathrm{E} \\
57^{\circ} 22^{\prime} \mathrm{N}, 11^{\circ} 20^{\prime} \mathrm{E}\end{array}$ & 9 & $\mathrm{x}$ & $\mathrm{X}$ & $\mathrm{x}$ \\
\hline Nov 2-4, 1990 & $\begin{array}{l}57^{\circ} 58^{\prime} \mathrm{N}, 10^{\circ} 49^{\prime} \mathrm{E} \\
56^{\circ} 40^{\prime} \mathrm{N}, 12^{\circ} 06^{\prime} \mathrm{E}\end{array}$ & 8 & $\mathrm{x}$ & & \\
\hline
\end{tabular}

Thorson' was also equipped with a Neil Brown (Mark III) CTD. Data collection procedures on this ship are described in Jakobsen et al. (1994). The CTD data were used to describe the density $\left(\sigma_{t}\right)$ and water column stability distribution along the transects. Light attenuation coefficients $k$ (Lambert-Beer: $I_{d}=I_{\mathrm{o}} \mathrm{e}^{-k d}$ ) were determinated at selected daylight stations on all cruises where primary production was measured. $k$ was determined using a $Q$ Instruments (Copenhagen) photometer (cosine collector) lowered through the water column. In situ measurements were corrected for changes in surface irradiance throughout the measuring period. In addition, a stability parameter (Simpson 1981):

$$
\phi=\frac{1}{h} \int_{-h}^{0}(\bar{\rho}-\rho) g z d z
$$

was calculated for each station down to a depth of $30 \mathrm{~m}$, where $h$ is the total depth (m), $\bar{\rho}$ is the mean density (from 0 to $h \mathrm{~m}$ ), $\rho$ is the density, $g$ is the gravitational acceleration, $z$ is the depth (m). Stability was calculated to a fixed depth in order to ensure differences noted between stations were related to water column characteristics and not depth differences. The fixed depth was chosen at $30 \mathrm{~m}$, as over $90 \%$ of the stations included in the study had a depth of $>30 \mathrm{~m}$. For those with a depth of less than $30 \mathrm{~m}$ (minimum depth $26 \mathrm{~m}$ ), the water column was artificially extended down to $30 \mathrm{~m}$ using the salinity and temperature values measured at the lowest depth. This comparison of stability between stations was also made using a fixed depth of $50 \mathrm{~m}$ (data not shown) and the same general pattern emerged (i.e. fronts were identified on the same cruises and at the same stations as when a depth of $30 \mathrm{~m}$ is used). Light attenuation coefficients (Lambert-Beer) made during this study varied between 0.18 and 0.32 . Accordingly, the $1 \%$ light penetration level would in all cases be $<30 \mathrm{~m}$. Thus, it is argued that the major part of the photosynthetic activity will be occurring in the upper $30 \mathrm{~m}$ of the water column in the study area. 
We define a front as being present on those transects where stability falls from over 200 to under $75 \mathrm{~J} \mathrm{~m}^{-3}$, and the front itself as being located at the station exhibiting the lowest stability along a transect from high to low stability. A truly mixed water column will yield a stability parameter of 0 . It often occurs in this region, however, that a shallow layer of lower salinity Kattegat water can be found at the immediate surface in a region where the waters above the pycnocline are otherwise primarily influenced by water of Skagerrak origin. In order to accommodate this situation, we chose to define a water column exhibiting a stability parameter of $<75 \mathrm{~J} \mathrm{~m}^{-3}$ as 'mixed'. We define the 'frontal region' as being the latitudinal boundaries within which we observe the presence of a front.

Nutrients. Nutrient determinations were made after the methods described by Grasshoff (1976). Full details of the procedures used can be found in Jakobsen et al. (1994).

Chlorophyll determination and fluorescence measurement. A Q Instruments fluorometer (Hundahl \& Holck 1980) was mounted on the CTD/rosette system on both ships. Chlorophyll a fluorescence was recorded simultaneously with temperature and salinity on the down cast of the CTD. Water samples for chlorophyll a determinations were collected at selected depths (usually 3 to 4 ) on the up cast of the CTD. Aboard RV 'Dana' these samples were filtered onto GF/C filters, extracted in $90 \%$ acetone and measured after the Lorenzen method (Strickland \& Parsons 1972). On RV 'Gunnar Thorson' they were filtered onto GF/C filters, extracted in $96 \%$ ethanol and measured after the Baltic Standard Method (Helcom 1988).

A regression of chlorophyll a versus fluorescence was defined for each cruise. In cases where the surface chlorophyll/fluorescence relationship differed from that of the rest of the water column, separate regressions were used to estimate chlorophyll distributions in the different water masses. Fluorescence measurements at ca $0.25 \mathrm{~m}$ intervals through the water column (to $30 \mathrm{~m}$ ) were converted to chlorophyll concentrations in order to calculate integrated chlorophyll (as a proxy for phytoplankton biomass) in the water column.

In addition, absorption at $480 \mathrm{~nm}$ and $665 \mathrm{~nm}$ was measured on acetone extracts from surface water samples on 12 cruises (Table 1) to investigate the nutritional status of phytoplankton cells (Heath et al. 1990). Accordingly, increases in this ratio were interpreted as indicating increased nutrient limitation of the phytoplankton community. When the ratio exceeded 2.0, the phytoplankton in the surface waters were presumed to be nutrient limited (Heath et al. 1990). On RV 'Gunnar Thorson' cruises, where chlorophyll extractions were made in ethanol, a calibration between measurements of $480: 665$ in acetone and ethanol was established.
Primary production. Samples for particulate primary production $(>0.22 \mu \mathrm{m})$ were collected and treated as described in Nielsen \& Richardson (1989) with the exception that when a subsurface chlorophyll peak was present, samples were taken at 2 depths: $2.5 \mathrm{~m}$ and in the subsurface chlorophyll maximum. When no subsurface chlorophyll maximum was present, sampling was made only at $2.5 \mathrm{~m}$. The only exception to this procedure was on the March 1992 cruise where a mixture of water sampled from 2.5, 5 and $10 \mathrm{~m}$ was incubated. The primary production at $1 \mathrm{~m}$ intervals throughout the surface mixed layer was calculated by: (1) finding the light at each depth (from measured attenuation coefficients and $I_{0}$ ), and (2) applying the P vs I relationship for the $2.5 \mathrm{~m}$ sample and correcting for the phytoplankton biomass (established from the fluorescence/chlorophyll relationship) at a given depth compared to that in the $2.5 \mathrm{~m}$ sample. A linear relationship between algal biomass and photosynthesis was assumed, i.e. a doubling in chlorophyll was assumed to correspond to a doubling of photosynthetic carbon incorporation.

The P vs I response established for the subsurface or pycnocline population was used to describe the photosynthetic characteristics of the phytoplankton below the surface mixed layer (as determined from the CTD profile) and the primary production occurring below the surface mixed layer was calculated as described above.

Potential daily primary production rates were established by applying measured attenuation coefficients and a model for average hourly insolation rates for Copenhagen, Denmark, at weekly intervals throughout the year supplied by Niels Ehler (The Royal Danish Veterinary and Agricultural University). In another study (Richardson \& Heilmann in press), we have shown that application of these light values to P vs I determinations made at various depths in the water column in the Kattegat during June generally compares well with those obtained from in situ photosynthesis determinations made at the same depths. Therefore, we believe that the application of the Ehler light model gives a reasonable approximation of light conditions in our study area. Even substantial differences between the actual and the model light conditions, however, would not affect the conclusions of our study, as our purpose was to examine whether or not phytoplankton activity is homogeneously distributed in the region surrounding the Kattegat/Skagerrak border. For this purpose, relative estimates of photosynthesis would be sufficient.

In order to estimate an annual primary production rate for the study area, it was necessary to assign a value for primary production for months where no data existed. To estimate the magnitude of primary produc- 
Table 2. Chlorophyll $a$ and primary production characteristics for all cruises. Chlorophyll $a$ concentration is given in $\mu \mathrm{g} \mathrm{l}^{-1}$. Surf. pigm./max. pigm. is the ratio of chlorophyll a measured at $2.5 \mathrm{~m}$ to the maximum recorded in the water column. $\mathrm{A}_{480} / \mathrm{A}_{665}$ is the absorption ratio in acetone extracts at 480 and $665 \mathrm{~nm}$. Assimilation index for $2.5 \mathrm{~m}$ and subsurface maxima phytoplankton is given as $\mu \mathrm{g} \mathrm{C}$ fixed ( $\mu \mathrm{g} \mathrm{chl})^{-1} \mathrm{~h}^{-1}$. Alpha is the initial slope of the P vs I curve in the $2.5 \mathrm{~m}$ and subsurface phytoplankton samples. Values are given as mean $\pm \mathrm{SD}$; number of samples is given in parentheses

\begin{tabular}{|c|c|c|c|c|c|c|c|}
\hline \multirow[t]{2}{*}{ Period } & \multirow{2}{*}{$\begin{array}{c}\text { Surface } \\
\text { chlorophyll }\end{array}$} & \multirow{2}{*}{$\begin{array}{l}\text { Surf. pigm./ } \\
\text { max. pigm. }\end{array}$} & \multirow{2}{*}{$\mathrm{A}_{480} / \mathrm{A}_{665}$} & \multicolumn{2}{|c|}{ Assimilation index } & \multicolumn{2}{|c|}{ Alpha } \\
\hline & & & & Surface & Subsurf. & Surface & Subsurf. \\
\hline Mar 2-3, 1992 & $\begin{array}{c}3.03 \pm 0.15 \\
\text { (9) }\end{array}$ & $\begin{array}{c}0.8 \pm 0.15 \\
(17)\end{array}$ & $\begin{array}{c}1.34 \pm 0.25 \\
\text { (9) }\end{array}$ & $1.78 \pm 1.21$ & - & $0.074 \pm 0.038$ & - \\
\hline Mar 11, 1992 & $\begin{array}{c}6.52 \pm 5.55 \\
(6)\end{array}$ & $\begin{array}{c}0.8 \pm 0.16 \\
(6)\end{array}$ & $\begin{array}{c}1.23 \pm 0.26 \\
(5)\end{array}$ & (16) & & $(16)$ & \\
\hline Apr 14,1984 & $\begin{array}{l}1.6 \pm 0.48 \\
(7)\end{array}$ & $\begin{array}{c}0.25 \pm 0.18 \\
\text { (7) }\end{array}$ & - & $\begin{array}{c}1.09 \pm 0.38 \\
(7)\end{array}$ & $\begin{array}{l}1.9 \pm 0.35 \\
(7)\end{array}$ & $\begin{array}{c}0.0055 \pm 0.0033 \\
(7)\end{array}$ & $\begin{array}{c}0.014 \pm 0.009 \\
\text { (7) }\end{array}$ \\
\hline All May data & $\begin{array}{c}1.07 \pm 0.73 \\
(73)\end{array}$ & $\begin{array}{c}0.49 \pm 0.27 \\
(73)\end{array}$ & $\begin{array}{c}1.69 \pm 0.35 \\
(71)\end{array}$ & $\begin{array}{c}2.99 \pm 1.21 \\
(38)\end{array}$ & $\begin{array}{c}1.69 \pm 1.26 \\
(24)\end{array}$ & $\begin{array}{c}0.025 \pm 0.017 \\
(31)\end{array}$ & $\begin{array}{c}0.052 \pm 0.046 \\
(26)\end{array}$ \\
\hline Jun $1-2,1987$ & - & $\begin{array}{c}0.47 \pm 0.17 \\
(7)\end{array}$ & - & - & - & - & - \\
\hline Jul 19-21, 1992 & - & $\begin{array}{c}0.29 \pm 0.18 \\
(6)\end{array}$ & - & - & - & - & - \\
\hline Aug 26, 1988 & $\begin{array}{c}1.74 \pm 1.03 \\
(6)\end{array}$ & $\begin{array}{c}0.46 \pm 0.45 \\
\text { (5) }\end{array}$ & $\begin{array}{c}1.96 \pm 0.25 \\
(5)\end{array}$ & - & - & - & - \\
\hline Sep 21-25, 1992 & $\begin{array}{c}0.83 \pm 0.31 \\
(5)\end{array}$ & $\begin{array}{c}0.15 \pm 0.07 \\
\text { (19) }\end{array}$ & $\begin{array}{c}1.88 \pm 0.53 \\
(6)\end{array}$ & $\begin{array}{c}2.31 \pm 0.92 \\
(6)\end{array}$ & $\begin{array}{c}1.5 \pm 1.0 \\
(5)\end{array}$ & $\begin{array}{c}0.024 \pm 0.011 \\
\text { (6) }\end{array}$ & $\begin{array}{c}0.033 \pm 0.023 \\
(5)\end{array}$ \\
\hline Oct 17,1990 & $\begin{array}{c}3.45 \pm 1.57 \\
(4)\end{array}$ & $\begin{array}{c}0.87 \pm 0.08 \\
(6)\end{array}$ & $\begin{array}{c}1.32 \pm 0.05 \\
(4)\end{array}$ & $\begin{array}{c}3.42 \pm 0.61 \\
(5)\end{array}$ & - & $\begin{array}{c}0.066 \pm 0.029 \\
(5)\end{array}$ & - \\
\hline Nov $2-4,1990$ & $\begin{array}{c}1.78 \pm 0.69 \\
(8)\end{array}$ & $\begin{array}{c}0.88 \pm 0.08 \\
(6)\end{array}$ & - & - & - & - & - \\
\hline
\end{tabular}

tion for June, the average chlorophyll a concentration, light attenuation coefficient and P vs I characteristics found during all 7 cruises in May were subjected to the average light conditions for mid-June (as indicated by the Ehler model). For the July primary production estimate, the water column characteristics for the September 1992 cruise were assumed and the light conditions for mid-July applied. We chose September water column characteristics rather than May, because the nitrate distribution in the water column in July is most similar to that recorded in September (see Fig. 5). It should be noted, however, that there is no significant difference between the photosynthetic characteristics (assimilation index and alpha) measured during May (all cruises) and September 1992 (Table 2).

Chlorophyll a distribution through the water column was measured in August 1988. This distribution along with an attenuation coefficient and photosynthetic parameters measured at similarly located stations on the September (1992) cruise were used along with August light conditions to estimate potential primary production during August.

Primary production characteristics from October 1990 were applied to the determined chlorophyll distributions and modelled light conditions for November in order to estimate the magnitude of November primary production. Values for primary production in the months of December, January and February were estimated by assuming the same chlorophyll distribution and light attenuation coefficient in the water column as observed in November 1990, the same P vs I response as observed in October 1990 and the average light conditions on the 15 th of the respective month. Because of the short but intense spring bloom observed in March 1992, potential primary production is given as 3 to $4 \mathrm{~d}$ averages for March rather than monthly averages as was the case for the remainder of the year.

\section{RESULTS}

The phytoplankton biomass (expressed as integrated water column chlorophyll or fluorescence) at all of the stations included in the study and plotted as a function of station latitude (Fig. 2) was shown to be significantly higher over an annual cycle $(\mathrm{p}<0.0001$; SAS GLM procedure) in the region between $57^{\circ} 25^{\prime} \mathrm{N}$ and $58^{\circ} 00^{\prime} \mathrm{N}$ than in the rest of the study area. Highest biomass values were recorded during the spring bloom (March 11, 1992). However, stations with elevated biomass 

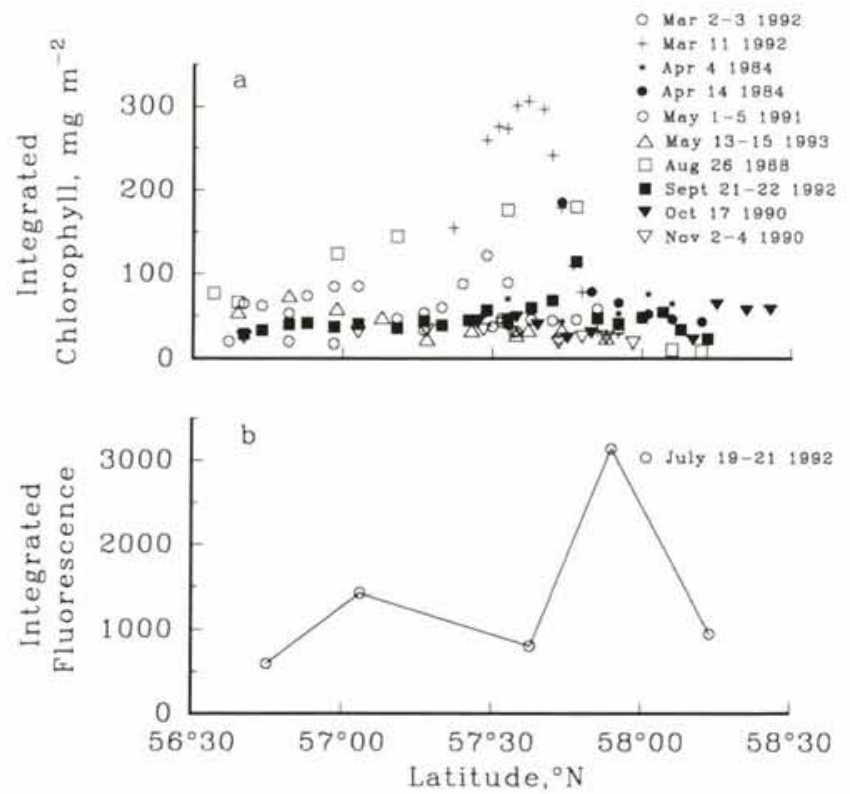

Fig. 2. (a) Phytoplankton biomass (expressed as depthintegrated chlorophyll to $30 \mathrm{~m}$ ) and (b) depth-integrated fluorescence (to $30 \mathrm{~m}$ ) for July 1992 where no chlorophyll a calibration was established, shown as function of station

latitude. The dates transects were sampled are indicated

occurred in this region throughout the productive spring and summer months when a front was recorded.

In Fig. 3, the phytoplankton biomass data from each of the transects used to compile Fig. 2 are plotted together with the stability parameter. The distribution of the stability parameter indicates that no front was present on 3 of the transects (Fig. 3c, e, f). For those transects carried out in the period from March to August when a front was observed, a phytoplankton biomass peak was associated with the front/frontal region. At the time of the spring bloom (Fig. 3a, b), the phytoplankton biomass peak recorded was associated with the weakly stratified waters at the southern edge of the front. Later in the spring/summer, the phytoplankton biomass peak coincided with the frontal station(s) exhibiting the lowest stability (Fig. 3d, g, h).

On the September transect (Fig. 3i), the minimum in stability was recorded at the northernmost Skagerrak station. No corresponding peak in phytoplankton biomass was recorded. In October and November (Fig. 3j, k), phytoplankton biomass was low. However, the highest concentrations were, as in March, associated with the stratified waters bordering the front.

The distribution of chlorophyll through the water column in relation to the distribution of $\sigma_{1}$ for 3 selected transects is shown in Fig. 4. Nitrate distributions are presented for 2 of these transects. On March 11, 1992 (Fig. 4a), chlorophyll was concentrated on the stratified side of the front. Relatively high chlorophyll concentra-

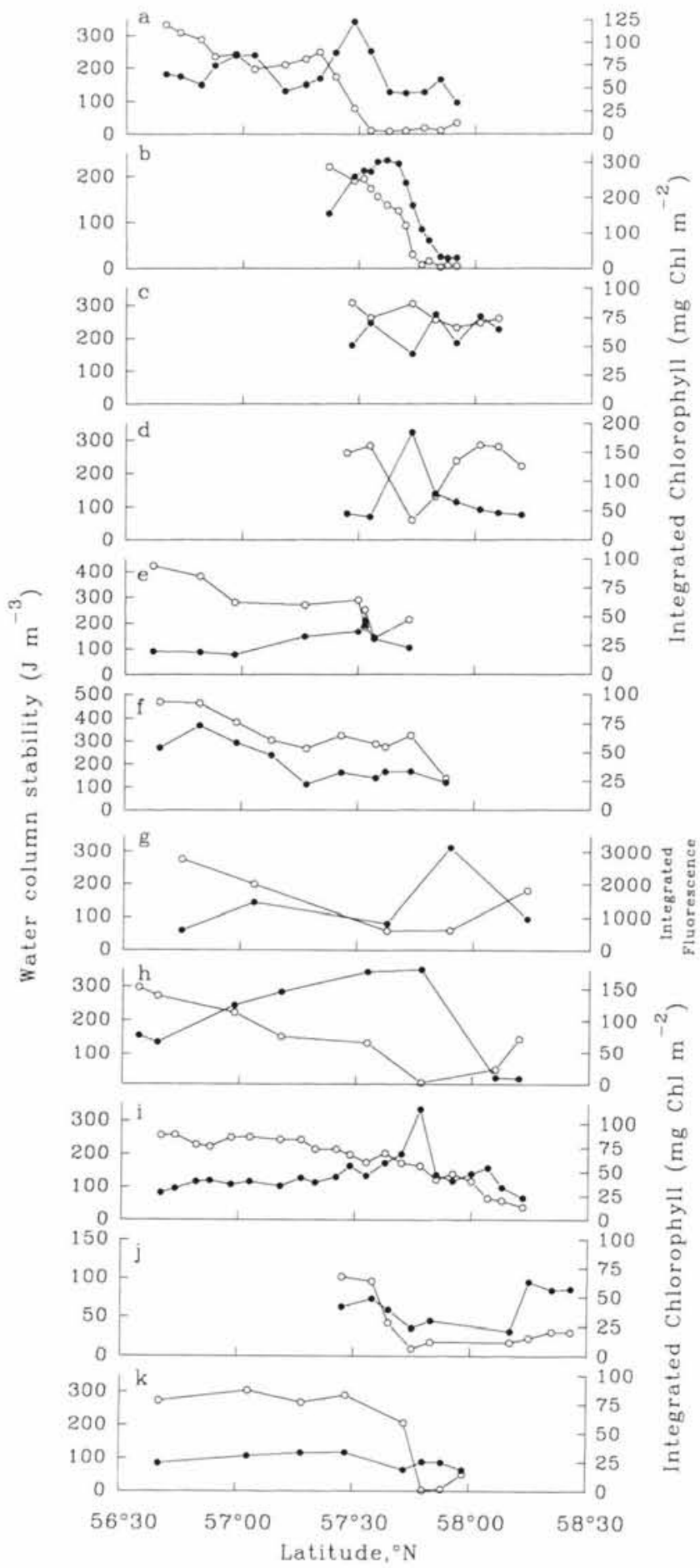

Fig. 3. Water column stability to $30 \mathrm{~m}(0)$ and integrated chlorophyll to $30 \mathrm{~m}(\bullet)$ as a function of station latitude along each transect (see Fig. 1). (a) Mar 2-3, 1992; (b) Mar 11, 1992; (c) Apr 4, 1984; (d) Apr 14, 1984; (e) May 1-4, 1991; (f) May 13-15, 1993; (g) Jul 19-21, 1992; (h) Aug 17-26, 1988;

(i) Sep 21-22, 1992; (j) Oct 17, 1990; (k) Nov 2-4, 1990

tions were recorded throughout the surface mixed layer. Nitrate was detectable in surface waters near the 


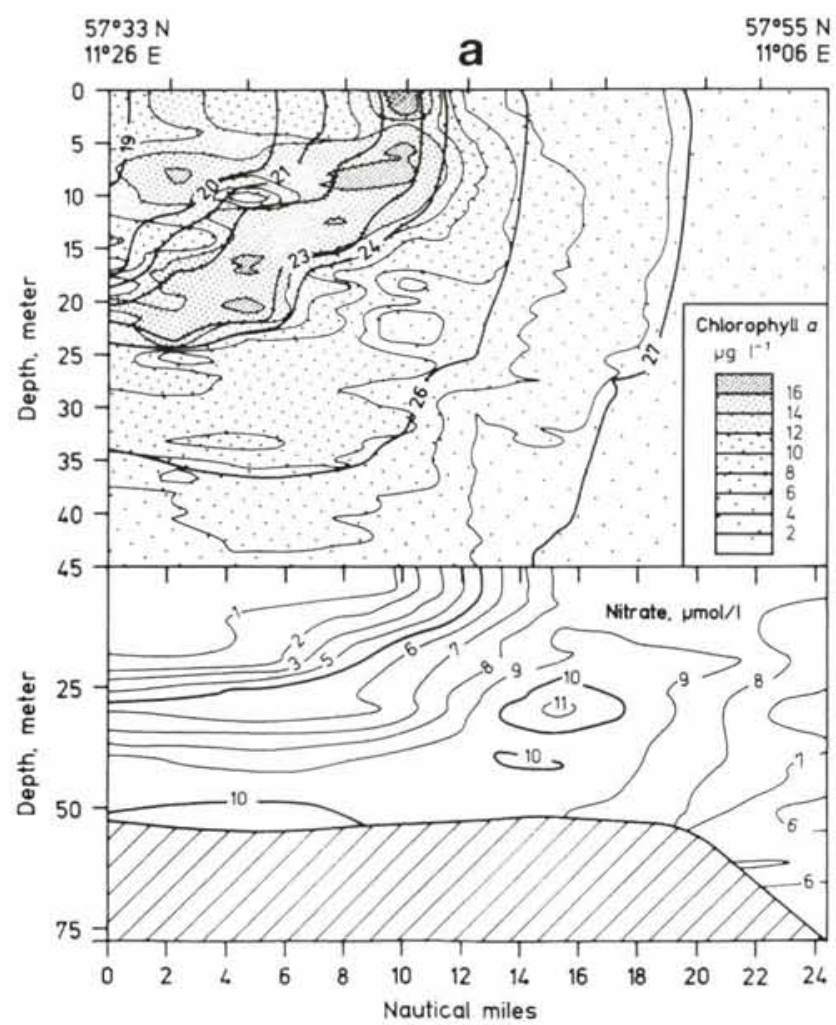

Fig. 4. Vertical transects of phytoplankton biomass (expressed as $\mu \mathrm{g}$ chlorophyll $1^{-1}$, shown by intensity of shading) and density $\left(\sigma_{t}\right.$, shown by isolines) for (a) Mar 11, 1992, (b) Apr 14, 1984, (c) Sep 21, 1992. For Mar 11, 1992 and Sep 21-22, 1992, respectively, the vertical transects of nitrate concentrations $\left(\mu \mathrm{mol} \mathrm{I}^{-1}\right)$ are shown below the chlorophyll and density distributions

front. Nitrate measurements carried out on March 2 to 3 indicated detectable concentrations in surface waters at all stations (Jakobsen et al. 1994). The chlorophyll distribution recorded on the March transect was in sharp contrast to those observed later in the spring/summer period when concentrations were generally highest at the most weakly stratified stations (i.e. April 14, 1984: Fig. 4b). On the September 21 to 22, 1992 transect, the greatest chlorophyll concentrations were located in the pycnocline (Fig. 4c). This subsurface chlorophyll layer was largest in the waters over a region where the lateral gradient of the isopycnals in
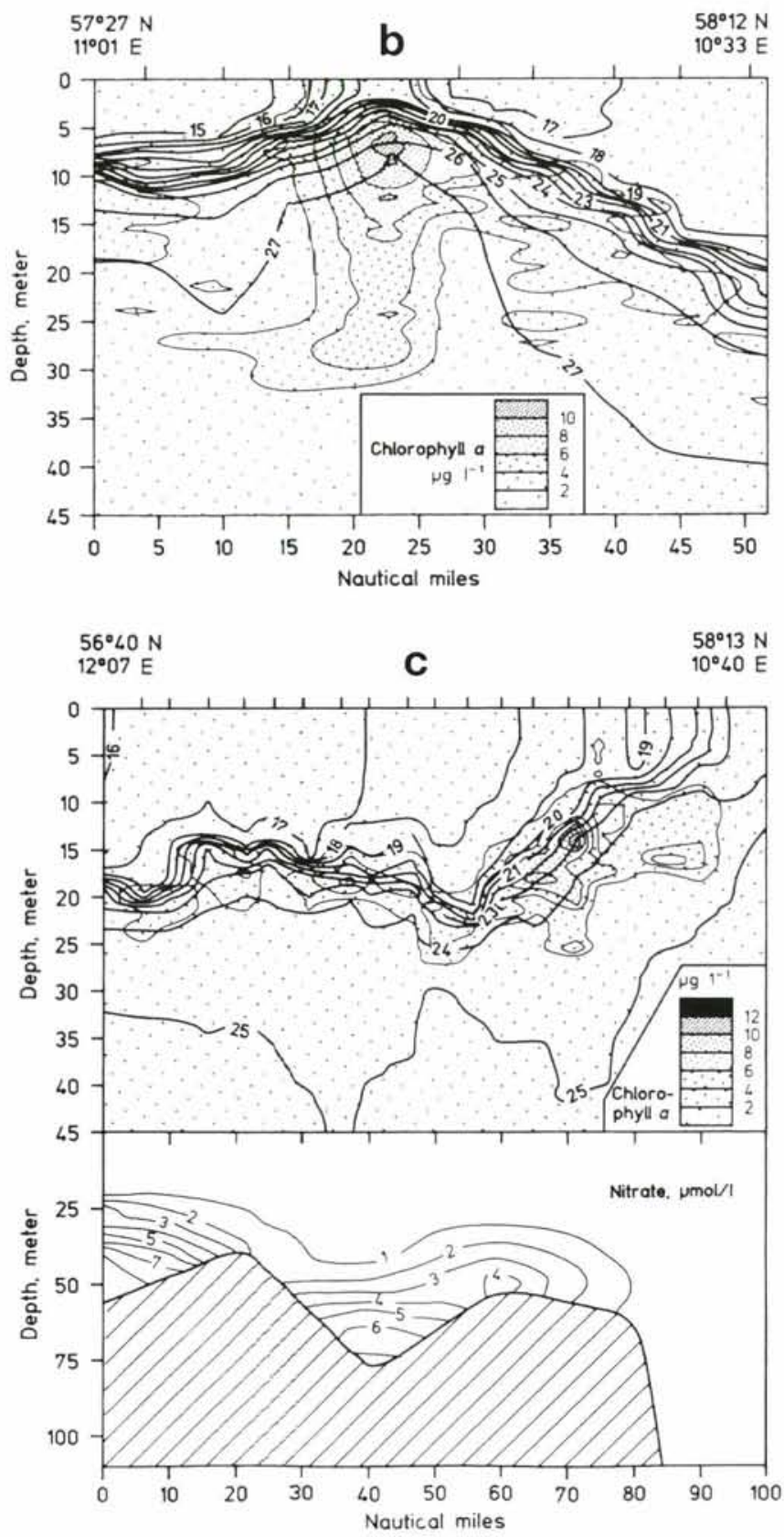

the vertical was maximal. This wide and dense subsurface chlorophyll patch was responsible for the biomass peak recorded in Fig. 3i.

The $480 \mathrm{~nm}: 665 \mathrm{~nm}$ absorption ratio in surface samples (Table 2) was low (<ca 1.5) at the beginning of the production period (March 2 to 3, March 11 and May 1 to 5) but climbed by May 13 to 15 to a level of ca 1.7. suggesting the onset of nutrient depletion in these samples. No measurements of 480:665 were made during most of the summer period. However, the ratio in August 26 was also high (ca 2.0) suggesting that nutrient depletion in surface waters may extend through 


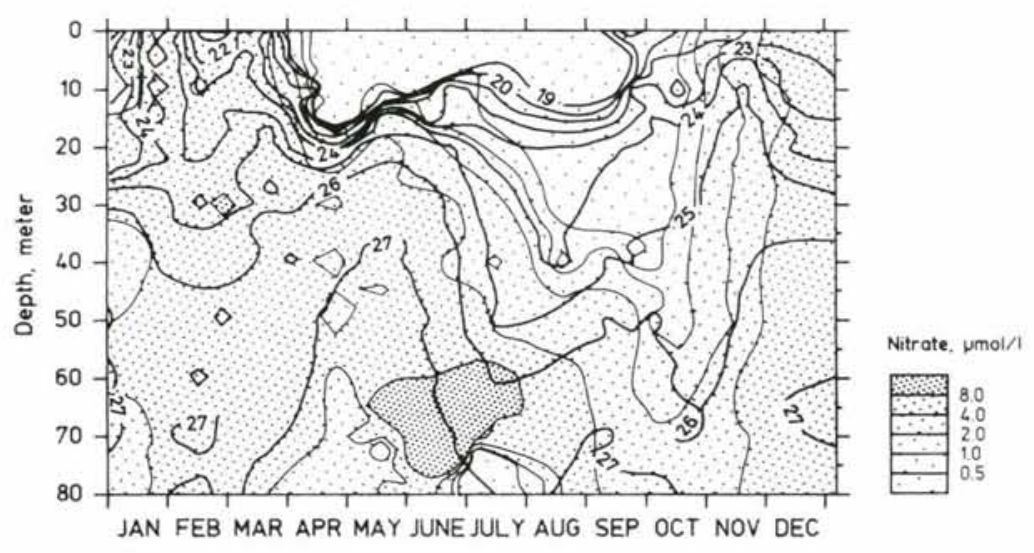

Fig. 5. Vertical nitrate distribution (shown by intensity of shading) and density $\left(\sigma_{t}\right.$, shown by isolines) recorded at a fixed position $\left(57^{\circ} 33^{\prime} \mathrm{N}, 11^{\circ} 31^{\prime} \mathrm{E}\right)$ in the study area in 1990

the summer months. After September 21 to 22, this ratio fell, indicating nutrient-replete conditions again.

Further evidence for nutrient limitation in the periods indicated by the $480: 665$ absorption ratio can be found in the water column nutrient distributions recorded in this region. Fig. 5 shows measurements, taken from the ICES data base, of the vertical distribution of nitrate at a fixed position $\left(57^{\circ} 33^{\prime} \mathrm{N}, 11^{\circ} 31^{\prime} \mathrm{E}\right)$ in the study area in 1990. Concentrations of $<0.5 \mu \mathrm{M}$ nitrate were recorded in surface waters from midMarch until mid-October.

Table 2 also shows the ratio of the chlorophyll concentration at $2.5 \mathrm{~m}$ divided by the maximum chlorophyll concentration measured in the water column. A value of 1.0 indicates that the maximum chlorophyll concentration occurred at the surface. Values of $<1.0$ indicate the presence of a subsurface peak. Thus, from the time immediately following the spring bloom there was evidence of a very strong subsurface chlorophyll maximum. Later in the summer, there was still a subsurface chlorophyll peak but it appeared to be somewhat weaker than in the early part of the summer. These peaks were generally located in the upper edge of the nutrient-rich bottom water which as a rule coincided with the pycnocline (Fig. 4c).

The estimated annual distribution of primary production is shown in Fig. 6. Spring and autumn peaks in production can be identified with the greatest variability (patchiness) occurring at the same time. Integration over time indicates an annual average primary production of $190 \mathrm{~g} \mathrm{C} \mathrm{m}^{-2} \mathrm{yr}^{-1}$. Primary production was not measured on all stations and the data set describing phytoplankton activity is weaker than that describing biomass. As a result, it was not possible to identify statistically significant differences in the production occurring within the different geographic regions of the study area. However, the phytoplankton in the frontal region were actively photosynthesising as evidenced by primary production determinations (Table 3).

The data collected from all of the May cruises are presented in Table 4. The 480: 665 absorption ratio indicates nutrient depletion of surface waters in 1988 and 1993. From the ratios for 1987, 1989 , 1990 , and 1992 , it is not possible to conclude whether or not nutrient depletion was likely in surface waters. However, the low ratio $(<1.5)$ in 1991 suggests that phytoplankton in surface waters were not nutrient-depleted during May 1991.

The ratio of chlorophyll concentration at $2.5 \mathrm{~m}$ to the maximum chlorophyll concentration in the water column can be used to examine interannual differences in the relative size of the subsurface chlorophyll peak. A subsurface peak was found on all of the May cruises included in the study but the amount of chlorophyll in the maximum relative to that at $2.5 \mathrm{~m}$ varied considerably from year to year. The most pronounced subsurface peak was in 1993 while the weakest was observed in 1989.

A significant difference ( $p<0.0001$ ) in the surface ( $2.5 \mathrm{~m}$ ) chlorophyll concentrations was observed over the 7 years for which there are May data. The highest values ( $x>2.0 \mathrm{mg}$ chlorophyll $\mathrm{a} \mathrm{m}^{-3}$ ) were observed in 1987 while the lowest $\left(x<0.5 \mathrm{mg}\right.$ chlorophyll $\mathrm{a} \mathrm{m}^{-3}$ ) were found in 1993. The differences observed between integrated chlorophyll in the upper $30 \mathrm{~m}$ of the water column were also significant but much less pronounced than those seen in surface waters from year to year.

Although considerable differences were observed in the distribution of chlorophyll $a$ in the water column, no significant $(p<0.43)$ difference could be demonstrated

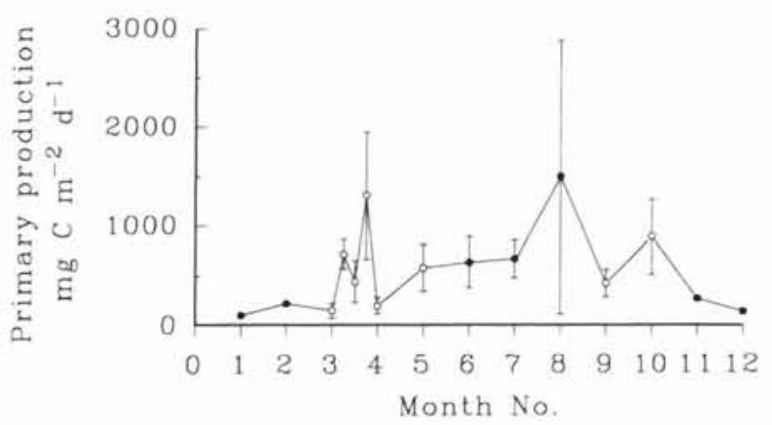

Fig. 6. Annual distribution of potential primary production rates $\left(\mathrm{mg} \mathrm{C} \mathrm{m}^{-2} \mathrm{~d}^{-1}\right.$, mean $\pm \mathrm{SD}$ ) in the entire study area. (o) Actual measurements; $(\bullet)$ constructed monthly averages (see text) 
Table 3. Distribution of available primary production estimates (given as $\mathrm{mg} \mathrm{C} \mathrm{m} \mathrm{m}^{-2} \mathrm{~d}^{-1}$ ) in and outside the frontal region $\left(57^{\circ} 25^{\prime}\right.$ to $\left.58^{\circ} 00^{\prime} \mathrm{N}\right)$

\begin{tabular}{|c|c|c|c|c|c|c|c|c|c|}
\hline \multirow[t]{2}{*}{ Period } & \multicolumn{3}{|c|}{$56^{\circ} 40^{\prime}-57^{\circ} 10^{\prime} \mathrm{N}$} & \multicolumn{3}{|c|}{$57^{\circ} 25^{\prime}-58^{\circ} 00^{\prime} \mathrm{N}$} & \multicolumn{3}{|c|}{$>58^{\circ} 00^{\prime} \mathrm{N}$} \\
\hline & Range & $\mathrm{n}$ & $\begin{array}{c}\text { Mean } \\
\pm \text { SD }\end{array}$ & Range & $\mathrm{n}$ & $\begin{array}{c}\text { Mean } \\
\pm \mathrm{SD}\end{array}$ & Range & n & $\begin{array}{l}\text { Mean } \\
\pm \mathrm{SD}\end{array}$ \\
\hline Mar 2-3, 1992 & 843 & 1 & 843 & $93-199$ & 2 & $146 \pm 75$ & 199 & 1 & 199 \\
\hline Mar 11,1992 & - & - & - & $611-2350$ & 5 & $1306 \pm 641$ & $194^{a}$ & 1 & 194 \\
\hline Apr 14,1984 & - & - & - & $115-355$ & 7 & $195 \pm 83$ & 192 & 1 & 192 \\
\hline May $22-24,1987$ & $611-970$ & 2 & $791 \pm 254$ & $483-1544$ & 2 & $986 \pm 533$ & - & - & - \\
\hline May $17-21,1988$ & - & - & - & $382-533$ & 3 & $475 \pm 81$ & - & - & - \\
\hline Apr 28-May 3, 1990 & $696-765$ & 2 & $730 \pm 49$ & $269-1302$ & 7 & $689 \pm 385$ & - & - & - \\
\hline May $1-5,1991$ & $356-395$ & 2 & $375 \pm 28$ & $410-1185$ & 6 & $615 \pm 346$ & - & - & - \\
\hline May $1-4,1992$ & $513-981$ & 2 & $747 \pm 331$ & $644-1140$ & 3 & $898 \pm 248$ & - & - & - \\
\hline May $13-15,1993$ & $339-637$ & 2 & $488 \pm 211$ & $400-1137$ & 7 & $599 \pm 247$ & - & - & - \\
\hline Sep $21-25,1992$ & 282 & 1 & 282 & $316-649$ & 5 & $444 \pm 135$ & $316-508$ & 3 & $410 \pm 96$ \\
\hline Oct 17,1990 & - & - & - & $411-1200$ & 4 & $879 \pm 375$ & - & - & - \\
\hline${ }^{a}$ From March 9, 1992 & & & & & & & & & \\
\hline
\end{tabular}

Table 4. Interannual variations (mean \pm SD) in characteristics derived from chlorophyll $a$ and primary production measurements for the May cruises. Integrated chlorophyll is to $30 \mathrm{~m}$. Primary production is given in $\mathrm{mg} \mathrm{C} \mathrm{m}^{-2} \mathrm{~d}^{-1}$. All other measurements are as described for Table 2

\begin{tabular}{|c|c|c|c|c|c|c|c|c|c|}
\hline \multirow[t]{2}{*}{ Year } & \multirow{2}{*}{$\begin{array}{l}\text { Surface } \\
\text { chlorophyll }\end{array}$} & \multirow{2}{*}{$\begin{array}{l}\text { Surf. pigm./ } \\
\text { max. pigm. }\end{array}$} & \multirow[t]{2}{*}{$\mathrm{A}_{480} / \mathrm{A}_{665}$} & \multirow{2}{*}{$\begin{array}{l}\text { Integrated } \\
\text { chlorophyll }\end{array}$} & \multicolumn{2}{|c|}{ Assimilation index } & \multicolumn{2}{|c|}{ Alpha } & \multirow{2}{*}{$\begin{array}{l}\text { Primary } \\
\text { production }\end{array}$} \\
\hline & & & & & Surface & Subsurf. & Surface & Subsurf. & \\
\hline 1987 & $\begin{array}{c}2.15 \pm 0.51 \\
(5)\end{array}$ & $\begin{array}{c}0.6 \pm 0.16 \\
(5)\end{array}$ & $\begin{array}{c}1.91 \pm 0.32 \\
\text { (5) }\end{array}$ & $\begin{array}{l}65 \pm 7.2 \\
(5)\end{array}$ & $\begin{array}{c}2.06 \pm 0.51 \\
(5)\end{array}$ & $\begin{array}{c}0.36 \pm 0.37 \\
\text { (4) }\end{array}$ & $\begin{array}{c}0.048 \pm 0.017 \\
\text { (5) }\end{array}$ & $\begin{array}{c}0.039 \pm 0.04 \\
\text { (4) }\end{array}$ & $\begin{array}{c}908 \pm 412 \\
\text { (5) }\end{array}$ \\
\hline 1988 & $\begin{array}{c}0.58 \pm 0.25 \\
\text { (9) }\end{array}$ & $\begin{array}{c}0.39 \pm 0.28 \\
\text { (9) }\end{array}$ & $\begin{array}{c}2.03 \pm 0.34 \\
\text { (9) }\end{array}$ & $\begin{array}{l}19 \pm 4.5 \\
\text { (9) }\end{array}$ & $\begin{array}{l}3.3 \pm 1.33 \\
\text { (4) }\end{array}$ & - & $\begin{array}{c}0.016 \pm 0.008 \\
\text { (4) }\end{array}$ & - & $\begin{array}{c}591 \pm 242 \\
\text { (4) }\end{array}$ \\
\hline 1989 & $\begin{array}{l}1.3 \pm 1.04 \\
(13)\end{array}$ & $\begin{array}{c}0.79 \pm 0.12 \\
(12)\end{array}$ & $\begin{array}{c}1.71 \pm 0.2 \\
\quad(12)\end{array}$ & $\begin{array}{c}47 \pm 29 \\
(8)\end{array}$ & - & - & - & - & - \\
\hline 1990 & $\begin{array}{c}0.77 \pm 0.24 \\
(8)\end{array}$ & $\begin{array}{c}0.57 \pm 0.28 \\
(12)\end{array}$ & $\begin{array}{c}1.51 \pm 0.22 \\
(12)\end{array}$ & $\begin{array}{c}28 \pm 9.6 \\
(12)\end{array}$ & $\begin{array}{c}4.16 \pm 1.27 \\
(8)\end{array}$ & - & $\begin{array}{c}0.029 \pm 0.007 \\
\text { (9) }\end{array}$ & - & $\begin{array}{c}699 \pm 334 \\
\text { (9) }\end{array}$ \\
\hline 1991 & $\begin{array}{c}1.29 \pm 0.59 \\
(12)\end{array}$ & $\begin{array}{c}0.36 \pm 0.19 \\
\text { (13) }\end{array}$ & $\begin{array}{c}1.25 \pm 0.21 \\
(12)\end{array}$ & $\begin{array}{c}29 \pm 10 \\
\text { (9) }\end{array}$ & $\begin{array}{c}2.9 \pm 1.63 \\
(8)\end{array}$ & $\begin{array}{c}2.29 \pm 1.15 \\
(7)\end{array}$ & $\begin{array}{c}0.029 \pm 0.007 \\
\text { (9) }\end{array}$ & $\begin{array}{c}0.044 \pm 0.04 \\
(8)\end{array}$ & $\begin{array}{c}697 \pm 355 \\
\text { (9) }\end{array}$ \\
\hline 1992 & $\begin{array}{c}1.16 \pm 0.44 \\
(12)\end{array}$ & $\begin{array}{c}1.71 \pm 0.21 \\
\text { (11) }\end{array}$ & $\begin{array}{r}31 \pm 4 \\
(12)\end{array}$ & $\begin{array}{c}2.81 \pm 0.53 \\
(12)\end{array}$ & $\begin{array}{c}2.54 \pm 1.42 \\
(5)\end{array}$ & $\begin{array}{c}0.045 \pm 0.012 \\
\text { (4) }\end{array}$ & $\begin{array}{c}0.058 \pm 0.03 \\
(5)\end{array}$ & $\begin{array}{c}838 \pm 255 \\
(4)\end{array}$ & (5) \\
\hline 1993 & $\begin{array}{c}0.38 \pm 0.1 \\
(8)\end{array}$ & $\begin{array}{c}0.17 \pm 0.09 \\
(9)\end{array}$ & $\begin{array}{c}2.03 \pm 0.12 \\
(9)\end{array}$ & $\begin{array}{c}41 \pm 17 \\
(10)\end{array}$ & $\begin{array}{c}2.07 \pm 0.51 \\
(7)\end{array}$ & $\begin{array}{c}1.43 \pm 0.65 \\
(9)\end{array}$ & $\begin{array}{c}0.008 \pm 0.006 \\
(10)\end{array}$ & $\begin{array}{c}0.068 \pm 0.07 \\
\text { (9) }\end{array}$ & $\begin{array}{c}575 \pm 232 \\
(9)\end{array}$ \\
\hline
\end{tabular}

in the water column primary production (mean $\pm \mathrm{SD}=$ $675 \pm 311 \mathrm{mg} \mathrm{C} \mathrm{m}^{-2} \mathrm{~d}^{-1}, \mathrm{n}=41$ ) observed during May.

\section{DISCUSSION}

This study indicates that phytoplankton biomass over an annual cycle is not homogeneously distributed in the area examined. Phytoplankton biomass was shown to be significantly higher in the northern Kattegat/southern Skagerrak between the latitudinal boundaries of $57^{\circ} 25^{\prime} \mathrm{N}$ and $58^{\circ} 00^{\prime} \mathrm{N}$ than in the rest of the study area. On 7 of the 8 occasions when a front was found, it was recorded within this region. The exception occurred on the September 1992 cruise (Fig. 3i) where there was a steady decline in stability going from south to north. Thus, it is difficult to precisely locate the front. However, the stability falls to about $75 \mathrm{~J} \mathrm{~m}^{-3}$ at approximately $58^{\circ} 00^{\prime} \mathrm{N}$ (i.e. at the northern boundary of the area we define as the 'frontal region').

It should be noted that using our front definition we cannot with certainty say that we are intersecting the border between Skagerrak and Kattegat waters per se. For example, in some cases, we may be sampling in an eddy. Nevertheless, the change in stability characteris- 
tics indicates that a front structure is present. On all but one occasion, the recorded fronts were accompanied by an associated phytoplankton biomass peak. It is not known whether these biomass maxima were the result of mesoscale processes or advection to the frontal region. However, the recorded P vs I characteristics combined with the measured light attenuation coefficients suggest that the phytoplankton associated with these maxima are photosynthetically active under in situ conditions.

During March, October and November, the phytoplankton biomass maxima associated with the front were found in the stratified waters bordering the front. The available nutrient data as well as 480:665 absorption ratios suggest that phytoplankton in surface waters were not nutrient limited at the time that these transects were carried out. Thus, a reduction in the depth of the surface mixed layer (where isopycnals approach the surface at the frontal border) in periods in which light and not nutrients is limiting may increase the light availability to phytoplankton and give rise to an increase in production (i.e. spring bloom). A similar relationship between the spring bloom and a frontal system separating waters of the southern Kattegat and Baltic outflow waters was earlier identified (Richardson \& Christoffersen 1991).

During the late spring and summer, when phytoplankton in surface waters were exhibiting signs of nutrient depletion (elevated 480:665 absorption ratios) and nitrate concentrations in surface waters were low or non-detectable, the phytoplankton biomass maxima were observed at the station(s) exhibiting a minimum in water column stability. Thus, when nutrient availability is apparently limiting in surface waters, the shallow pycnocline near the front results in nutrientrich bottom water higher up in the photic zone. It seems likely that the combination of high light and improved nutrient conditions in surface waters at the front stimulates phytoplankton production at this time.

The annual primary production estimated for this area is $190 \mathrm{~g} \mathrm{C} \mathrm{m}^{-2} \mathrm{yr}^{-1}$ (Fig. 6). This value may be questioned because we have had to estimate the magnitude of primary production for 7 mo of the year. We would argue, however, that ours is a reasonable estimate for the following reasons:

(1) Four of the months (November, December, January and February) for which we estimate primary production are in the winter when light is predicted to be limiting and phytoplankton biomass is low. Our estimates for these months agree well with those obtained by Steemann Nielsen during the period 1954 to 1960 (Steemann Nielsen 1964) for these months [see Richardson \& Heilmann (in press) where the present data are recalculated using only the depths considered by Steemann Nielsen].
(2) The remaining 3 mo for which we estimate production are in the stable summer period (June, July and August). Fluorescence and chlorophyll measurements (Table 2) indicate the presence of a subsurface chlorophyll peak during all 3 mo. The 480:665 absorption ratios found during August indicate that, as in May and September, phytoplankton in surface waters are nutrient limited. The annual distribution of nitrate in this area (Fig. 5) suggests that this ought to be the case for June and July as well. Finally, we are unable to demonstrate a significant difference in the photosynthetic characteristics measured in May and September. We believe that the similarity in chlorophyll distributions and nutrient conditions during the summer period will result in reasonable primary production estimates using our assumptions. Richardson \& Heilmann (in press) have demonstrated that primary production measurements made during the period March to October during the 1980 s and 1990s are substantially higher than those made at the same time of the year by Steemann Nielsen in the 1950s (Steemann Nielsen 1964). They argue that this difference is a result of the increase in nutrient input to this region since the 1950s. Therefore, it is not possible to confirm our summer estimates of primary production by comparing them to Steemann Nielsen's results from the 1950s.

Richardson \& Christoffersen (1991) arrived at a somewhat higher estimate of annual primary production $\left(290 \mathrm{~g} \mathrm{C} \mathrm{m}^{-2} \mathrm{yr}^{-1}\right)$ at a fixed position in a region influenced by a front $\left(56^{\circ} 11^{\prime} \mathrm{N}, 12^{\circ} 04^{\prime} \mathrm{E}\right)$ in the southern Kattegat during 1989. However, they measured total primary production (i.e. particulate and dissolved organic). Therefore, their estimate would be expected to be somewhat higher than ours.

Several authors (e.g. Richardson \& Kullenberg 1987 , Lindahl 1993) have identified the coastal region in and near the frontal region discussed here as being frequently affected by 'unusual' or harmful algal blooms. At least one of the species implicated in these blooms (Gyrodinium areolum) is known to be associated with a frontal system in the Western English Channel (Holligan 1979). Therefore, we believe that future studies of the phytoplankton dynamics in the Skagerrak/Kattegat frontal region may lead to a better understanding of bloom formation in this area.

The comparison presented here of phytoplankton distribution and activity in the study area during May in the years 1987 to 1993 already allows some interesting observations with respect to the Chrysochromulina polylepis bloom in 1988. The 1988 May cruise was carried out at the time of the C. polylepis bloom when the subsurface chlorophyll peak was dominated by this organism. It has been argued (e.g. Maestrini \& Granéli 1991) that an exceptional inflow of nutrients (possibly via the Jutland Coastal Current) to the area may have 
fueled the bloom, the implication being that 1988 was an exceptional year in terms of phytoplankton development.

However, from the data presented here (Table 4), it is not possible to identify any exceptional characteristic in phytoplankton distribution or activity during this year in comparison to the other May cruises included in the study. In fact, the integrated phytoplankton biomass (chlorophyll to $30 \mathrm{~m}$ ) appears to be lower in May 1988 than in all other study years. There was evidence of a large subsurface chlorophyll maximum in 1988 but those observed in 1991 and 1993 were at least as distinct. In short, it would appear that the phytoplankton biomass, production and distribution in the water column in 1988 at the time of the Chrysochromulina polylepis bloom were typical for this time of year in the study region.

Another interesting observation is that despite a more than 4 -fold difference in the average chlorophyll a concentration in May at $2.5 \mathrm{~m}$, no significant difference among years could be established in the primary production. This finding may be of significance for monitoring programs where chlorophyll concentration is often used as a proxy for primary production.

We believe that the good year-to-year agreement in our May primary production measurements may be in part be a function of the fact that we took our samples for primary production determinations from 2 depths: $2.5 \mathrm{~m}$ and the depth of the subsurface chlorophyll maximum (if present) as established by fluorescence profiles. This flexible schedule enabled us to establish the photosynthetic characteristics of the phytoplankton in both the surface mixed layer and in the nutrient-rich waters below the surface mixed layer but still in the photic zone. Richardson \& Christoffersen (1991) have shown this subsurface phytoplankton population to be an important contributor to water column productivity in the southern Kattegat. The same would also appear to be the case in the region examined here although the relatively few primary production data collected during the summer months in this study do not allow a quantification of the role subsurface phytoplankton peaks play in total water column production.

Acknowledgements. We thank Alice Christoffersen who carried out the primary production measurements on all but one of the cruises used in the study. This work was partially funded by Marine Research Program 90 of the Danish Environmental Ministry.

\section{LITERATURE CITED}

Grasshoff, K. (1976). Methods of seawater analysis. Verlag Chemie, Weinheim

Heath, M. R., Richardson, K., Kiørboe, T. (1990). Optical assessment of phytoplankton nutrient depletion. J. Plankton Res. 12 (2): 381-396
Helcom (1988), Guidelines for the Baltic Monitoring Programme for the third stage. Part D. Biological determinands. Balt. Sea Environ. Proc. No. 27D, p. 1-166

Holligan, P. M. (1979). Dinoflagellate blooms associated with tidal fronts around the British Isles. In: Taylor, D. L., Seliger, H. H. (eds.) Toxic dinoflagellate blooms. Elsevier, Amsterdam, p. 249-256

Hundahl, H., Holck, J. (1980). A new in situ fluorometer for detection of Rhodamine B and chlorophyll. Report No. 42, Institute of Physical Oceanography, Univ. of Copenhagen, p. $145-154$

Jakobsen, F., A.rtebjerg, G., Agger, C. T., Højerslev, N. K., Holt, N., Heilmann, J. P., Richardson, K. (1994). Hydrografisk og biologisk beskrivelse af Skagerrakfronten. Havforskning fra Miljøstyrelsen. Miljøministeriet, Miljøstyrelsen

Lindahl, O. (1993). Hydrodynamical processes: a trigger and source for flagellate blooms along the Skagerrak coast? In: Smayda, T. J., Shimizu, Y. (eds.) Toxic phytoplankton blooms in the sea. Elsevier, Amsterdam, p. 775-781

Maestrini, S. Y., Granéli, E. (1991). Environmental conditions and ecophysiological mechnisms which led to the 1988 Chrysochromulina polylepis bloom: an hypothesis. Oceanol. Acta 14(4): $397-413$

Nielsen, T. G., Løkkegaard, B., Richardson, K., Pedersen, F. B., Hansen, L. (1993). The structure of the plankton communities in the Dogger Bank area (North Sea) during a stratified summer situation. Mar. Ecol. Prog. Ser. 95: $115-131$

Nielsen, T. G., Richardson, K. (1989). Food chain structure of the North Sea plankton communities: seasonal variations of the role of the microbial loop. Mar. Ecol. Prog. Ser. 56: $75-87$

Poulsen, O. (1991). The hydrography of Skagerrak and Kattegat, the dynamics of the Skagerrak front. Series Paper 54 . Institute of Hydrodynamics and Hydraulic Engineering, Technical University of Denmark

Richardson, K. (1985). Plankton distribution and activity in the North Sea/Skagerrak-Kattegat frontal area in April 1984. Mar. Ecol. Prog. Ser. 26: 233-244

Richardson, K. (1991). Comparison of ${ }^{14} \mathrm{C}$ primary production determinations made by different laboratories. Mar. Ecol. Prog. Ser. 72: 189-201

Richardson, K., Christoffersen, A. (1991). Seasonal distribution and production of phytoplankton in the southern Kattegat. Mar. Ecol. Prog. Ser. 78: 217-227

Richardson, K., Heilmann, J. P. (in press). Primary production in the Kattegat: past and present. Ophelia

Richardson, K., Kullenberg, G. (1987). Physical and biological interactions leading to plankton blooms: a review of Gyrodinium aureolum blooms in Scandinavian waters. Rapp. P.-v. Réun. Cons. int. Explor. Mer 187: 19-26

Rohde, J. (1992). Studies of currents and mixing in the Skagerrak. Doctoral thesis, Dept of Oceanography, University of Gothenburg

SAS Institute, Inc. (1981). SAS for linear models. A guide to the ANOVA and GLM procedures. SAS Institute, Inc., Cary, NC, p. $85-120$

Simpson, J. H. (1981). The shelf-sea fronts: implications of their existence and behaviour. Phil. Trans. R. Soc. 302 A: 531-546

Steemann Nielsen, E. (1964). Investigations of the rate of primary production at two Danish light ships in the transition area beween the North Sea and the Baltic. Meddelser fra Danmarks Fiskeri- og Havundersøgelser 4(3): 31-77

Strickland, J. D. H., Parsons, T. R. (1972). A practical handbook of seawater anlysis. Bull. Fish. Res. Bd Can. 167: $1-310$

Manuscript first received: September 23, 1993

Revised version accepted: June 23, 1994 